\title{
Is Batik Bad for Water and The Environment? Reveal The Perception of Batik Craftsmen About Environmental Care
}

\author{
$1^{\text {st }}$ Witha Ananda Putri ${ }^{1}, 2^{\text {nd }}$ Atia Rahmah ${ }^{2}, 3^{\text {rd }}$ Rynda Mayasari ${ }^{3}, 4^{\text {th }}$ Nurmita $^{4}, 5^{\text {th }}$ Deliza $^{5}, 6^{\text {th }}$ \\ Wiji Utami ${ }^{6}, 7^{\text {th }}$ Tanti $^{7}, 8^{\text {th }}$ Reza Ma'ruf ${ }^{8}$ \\ \{witha.putri10@gmail.com ${ }^{1}$, nurainahinah993@gmail.com², mayasarirynda@gmail.com ${ }^{3}$, \\ mitanur012v@gmail.com , deliza@uinjambi.ac.id ${ }^{5}$, wijiutami@uinjambi.ac.id ${ }^{6}$, tanti@uinjambi.ac.id ${ }^{7}$, \\ rezamaruf@uinjambi.ac.id $\left.{ }^{8}\right\}$
}

Universitas Islam Negeri Sulthan Thaha Saifuddin Jambi, Indonesia ${ }^{1,2,3,4,5,6,7,8}$

\begin{abstract}
Research on the use and management of dyes in the dyeing process of Jambi batik has been carried out with a qualitative approach. This research aims to determine the types of dyes used in the batik dyeing process and determine waste management. Researchers follow the phenomenology approach, with an in-depth analysis of synthetic dyes used by batik craftsmen and the methods used by batik craftsmen in processing these dyes before being dumped into the river. Batik craftsmen use synthetic direct dyes because they are considered more practical and durable than natural dyes. Craftsmen have not fully processed the dye waste before being discharged into the environment. Therefore, the government, ulama, and universities are very much needed in advocacy and training on wastewater treatment. This study provides an exciting opportunity to advance the knowledge of researchers and the public about synthetic dyes in the batik process and increase the awareness of batik craftsmen to the environment.
\end{abstract}

Keywords: Batik Jambi Industry, Environmental, Danger of Dyes.

\section{Introduction}

Batik is the Indonesian people's work, a combination of art and technology by the nation's ancestors and is known to foreign countries. UNESCO has designated Batik as an intangible cultural heritage belonging to Indonesia on October 2, 2009. The world recognizes Indonesian Batik because it has distinctive characteristics and contains various philosophical meanings about real-life wisdom. Since this recognition, the government has advised civil servants to use Batik on certain days, especially on the commemoration of National Batik Day. Since then, Batik has developed faster than in previous years [1]. Historically, Batik was brought by the Sumerians and developed in Indonesia, especially on the island of Java. Even Batik is a source of their livelihood. Apart from Java, batik is also spread from Sabang to Merauke [2] Patterns and colors in Batik have their own interests. Each region has a distinctive style and color [3]. Batik in Solo and Yogyakarta found a very distinctive style. As a rural batik motif, it has a philosophical meaning which in its use depends on the customs and beliefs that are believed in that area. Usually, the craftsmen produce Batik. It's different with the craftsmen who are on the coast who have more diverse patterns and colors. The patterns on Batik in coastal areas usually have meaning from the things around them. This means that the 
development of motifs on Batik in Indonesia is not static but dynamic. Making Batik cannot be separated from the coloring process, whether it is washing, dyeing, drawing, canting, coloring, and others, so of course, it produces a large quantity of dye waste.

The existence of Batik can be a textile industry sector that boosts the economy in Indonesia. According to the Ministry of Industry data, there were 47,755 MSME units in the batik industry in 2015 and spread throughout Indonesia. Based on research conducted by Abi Pratiwa Siregar et al., Indonesia achieved a batik production value of around 407.5 billion rupiahs per month or the equivalent of 4.89 trillion rupiahs per year [1] The development of the batik industry is due to a large number of market demands, not only in the growth of the market in Indonesia but also in foreign countries. In other words, the dye waste will increase, which is produced by the batik industry. Indonesian Batik is recognized as having dominated the world market, as evidenced by the achievement of batik exports of 58.46 million dollars in 2017 with the central destination countries, namely Japan, the United States, and [4]. Please note that batik products are not only in the form of clothes, but Batik can be in paintings or accessories such as necklaces, bags, shoes, and so on. The batik industry in Indonesia is overgrowing, and the batik industry in Jambi is no exception. However, interest in Batik is both an opportunity and a challenge. The great demand for Jambi Batik products has resulted in an increase in liquid waste from the dyeing process by Batik craftsmen [5]. The batik industry uses several types of dyes; some use natural dyes and synthetic dyes. Recently there has been a high interest in synthetic dyes because they are more practical, and the durability of dyes is longer than natural dyes. While synthetic dyes are mutagenic, carcinogenic which can trigger cancer for living things and can hinder the process of photosynthesis in water because of the remnants of wax and the dense color of the waste prevents the sun from interacting with water and pollutes the aquatic environment which disturbs the ecosystem in the waters [6]. The awareness and knowledge of batik craftsmen who are still low about the management of liquid waste from the batik coloring process contribute to pollution.

From the above background, the researcher aims to research Jambi Batik craftsmen by clarifying and knowing the types of dyes used and how the craftsmen treat dye waste. If the waste is released into the environment without treatment, it will damage the environment and specifically to water bodies. Meanwhile, we both know that Jambi has a long river, namely the Batanghari River, which is still used by the Jambi community to irrigate their plantations and fish. Therefore, we must ensure and create a sustainable batik industry following SDGs (Sustainable Development Goals) Numbers 6 and 12 concerning clean water and sanitation and ensure responsible consumption and production patterns to achieve environmentally friendly management of chemicals. And how can craftsmen be able to manage batik dye waste from chemicals to be ecologically friendly? As well as being able to reduce the release of these materials into the environment significantly.

\section{Literature Review}

\section{Batik Industry}

The industry is classified into two based on the Indonesian Classification of Business Fields (KLUI): small sectors, economic activities with 5-19 workers, and large sectors, with 100 or more workers. [7] Batik is a painting or drawing on cloth. It is made using Canting. Meanwhile, according to [8] Batik draws on the fabric using a barrier dyeing technique with wax as a color guide and batik pattern. 
Batik is the art of drawing on cloth for clothing. This image art is an image motif that has a philosophical meaning. The motifs in Batik are generally closely related to Javanese culture[9]. However, with the spread of Batik throughout the archipelago, the motifs on batik cloth follow the culture of each region where Batik originated. For example, Jambi batik, Jambi batik has a very different Malay motif from Javanese batik motifs which are identical to Javanese culture. The batik industry is a company that carries out the process of waxing with wax, dyeing with dyeing techniques, and heating with a shedding technique on the fabric to produce batik fabrics with smooth motifs [10]. Batik is an Indonesian cultural heritage. Batik is widespread throughout Indonesia, with different patterns and motifs in each region. The spread of Batik is also accompanied by the number of batik industries in Indonesia. The largest batik-producing industry is still attached to the island of Java, and this is shown by $80 \%$ of the batik industry spread across West Java (38.42\%), Central Java (26.22\%), Yogyakarta Special Region (DIY) (19.52\%). East Java $(2.66 \%)$, Banten $(0.23 \%)$, and the Special Capital Region (DKI) Jakarta $(0.05 \%)$. Meanwhile, outside Java, the largest batik industry is in Jambi province Jambi [1] Jambi batik has competitiveness in local and national markets. This is influenced by several factors, including product specifications, infrastructure, government policies, human resources, and Science and Technology (IPTEK).

\section{Danger of Dyes}

Indonesia has set a national batik day since October 2, 2009. Since then, the turnover of Batik sales has increased to $50 \%$. Judging from the data held by the Ministry of Industry, it was recorded that until October 2017, there was a significant increase in the value of batik production and exports of USD 51.15 million. In line with the significant increase in the number of batik industries, the resulting waste also increases. [11] According to Enrico 2019, the types of waste are divided into four parts, namely solid waste, liquid waste, gas waste, and waste containing hazardous and toxic materials (B3). The capacity of substances in the waste of these substances must harm the environment and health; the more waste, the more dangerous the impact, but if there is a little waste disposal, the danger of the waste effect will be reduced.

There are two types of dyes for Batik, namely natural dyes and synthetic dyes. In general, synthetic dyes are dyes that are processed through certain chemical reactions and have aromatic hydrocarbon derivatives such as benzene, toluene, daftalene, and anthracene. These dyes are stable and easy to use. Many synthetic dyes can be used for fabrics and textiles, but to be processed as batik dyes, the substances commonly used are Naphthol, Indigosol, Remasol, Rapid Dyes, and Direct Dyes. Natural dyes are also dyes obtained directly or indirectly from nature, these dyes are taken from plant and plant extracts such as leaves, fruit, bark, roots and so on. Similar to synthetic dyes, these dyes also have many types of materials that can be used as dyes, but what is often used by Batik is Secang which can produce a red color, Coconut Coir produces a brown color, Mangosteen rind produces a purplish red color, Turmeric produces a yellow color, and Indigofera plants that can produce a blue color. One of the wastes generated from the batik industry is synthetic dye waste. The waste is nonbiodegradable and cannot be decomposed, causing damage to the environment. Meanwhile, waste disposal carried out in the batik production process is usually carried out in bodies of water such as rivers.

Azo groups such as Remazol red RB are synthetic dyes that are usually used in the textile industry with a capacity of more than $70 \%$. [11]. In addition to Remazol red RB, Methylene blue dye is also a type of complex compound that is Non-Biodegradable and has a benzene 
structure that is difficult to decompose in the environment. Not only that, this dye is also harmful to health [12]. The waste substances produced in the textile dyeing process are synthetic chemical compounds, have a strong pollution power with high COD (Chemical Oxygen Demand) and BOD (Biological Oxygen Demand) values. The results of one of the experiments conducted at the BBT laboratory (Balai Besar Tekstil) showed that water from textile wastewater contains some reactive dyes as much as $225 \mathrm{mg} / \mathrm{l}$, has a COD of $534 \mathrm{mg} / \mathrm{l}$ and a BOD of $99 \mathrm{mg} / \mathrm{l}[13]$. When this type of dye is injected into the body, it will cause burns to the eyes, if inhaled it will have an impact on breathing, and if ingested, it will produce a burning sensation accompanied by nausea, vomiting, excessive sweating, and can even lead to permanent injury[12].

Quoting from Enrico 2019, there are several negative impacts caused by waste disposal, especially liquid waste such as dyes, including:

1. Pollution of surface water that humans will use.

2. Damage to life and aquatic ecosystems.

3. Generate odor (the result of decomposition of anaerobic and inorganic substances)

4. Produces mud which causes blockages and can cause flooding

\section{Synthetic Color Effect To The Environment}

The dyeing and textile industries release significant quantities of toxic-colored wastewater into the environment. Synthetic dyes in wastewater are toxic, carcinogenic, resistant to aerobic digestion, and stable to oxidizing agents. Adsorption is one of the most economical and applicable methods for removing textile organic pollutants from wastewater. Chitosan, the new biosorbent carrier amino and hydroxyl groups that act as active chelating sites, has been widely used in wastewater treatment because of its high adsorption capacity for dyes and pollutant advantages such as low cost, non-toxicity, and biodegradable characteristics. This natural biopolymer is a hydrophilic cationic macromolecule. However, the disposal of used chitosan limits its application and can cause secondary damage to environmental problems. Therefore, the chitosan adsorbent regeneration method is always concerned with reducing costs and environmental impact. One of them is the incorporation of $\mathrm{TiO} 2$ nanopowder in chitosan, where the functional group in chitosan plays a role in capturing dyes from aqueous solutions, and the addition of $\mathrm{TiO} 2$ causes degradation of adsorbed pollutants in chitosan so that biosorbents can be recovered, followed by a collection system [14].

The textile industry is known to consume large amounts of water throughout the production process. For example, $1 \mathrm{~kg}$ of textile manufacture consumes about 200 to $400 \mathrm{~L}$ of water [15]. Also, this industry uses different chemicals during the process, such as dyes, hydrogen peroxide, surfactants, dispersing agents, acids, bases, etc. Applying synthetic dyes for dyeing textile raw materials during the dyeing stage imparts intense color to residual waste, affects water transparency and photosynthetic activity, is toxic, carcinogenic, and mutagenic, and causes severe damage to human health the environment. A series of physical, chemical, and biological treatments have been used. For color removal of textile waste, like filtration, flocculation, adsorption, reverse osmosis, ion exchange, oxidative processes, fento, ozonation, electrochemical crushing, bioremediation system for dyes, mold discoloration, and enzyme treatment.

Waste from the textile industry is very important because it contains many contaminants, such as surfactants, dyes, peroxides, salts, acids, metals, suspended solids, and organic compounds, and other additives. The high solubility, residual color, and low biodegradability of many of these compounds require additional cleaning efforts. In this regard, combined 
processing appears as a possibility, where activated sludge systems and Advanced Oxidative Processes (AOPs) can increase the efficiency of organic degradation. About 72 toxic chemicals have been identified in textile waste, and it is estimated that around 200 billion liters of waste are produced annually worldwide by the textile industry. Many adverse effects have been identified as hundreds of contaminants are diluted in aquatic systems, affecting dissolved oxygen, turbidity, color, temperature, and, consequently, marine organisms. In this regard, the potential relationship between effluent toxicity and chemical oxygen demand has been discussed by [16].

\section{The Contribution of SDGs Research Towards a Sustainability Industry}

The rise of the batik industry that uses synthetic dyes contributes to environmental pollution. Batik craftsmen chose synthetic dyes because they are easier to use and easier to find than natural dyes. Synthetic dyes have more color choices and longer color resistance. This causes physical and functional disturbances in the environment, such as waters caused by the content of synthetic dyes that are biodegradable[17]. Most batik craftsmen do not treat batik wastewater first but instead dump it directly into the river. The awareness of batik craftsmen to manage wastewater from the selection of dyes and the coloring process is very important to create a sustainable batik industry following SDGs (Sustainable Development Goals) number 6 regarding water and sanitation. If water has the appropriate physical and function, it will create SDGs ( Sustainable Development Goals ) in goal number 12 regarding sustainable consumption and production. In addition to the effect on the environment, the use of synthetic dyes and paraffin wax can damage human skin and cause dangerous diseases [18]. This shows that every batik industry must have an AMDAL [19]. Lack of wisdom in managing water can lead to pollution and water scarcity. The water used for the batik production process affects the quantity and quality of water around the production site [20]. This research also makes the government aware that it is essential to make Jambi City regulations that are more assertive in managing wastewater, for example, in the batik industry. Regional regulations on industrial procedures for managing wastewater can control, maintain, protect, maintain, and increase efforts to preserve the environment, especially rivers, to create a sustainable industry. In addition to local regulations, the batik industry must also have environmentally friendly management from material selection, processing, storage, distribution, and management of the workforce to produce effective production in all fields to create a sustainable industry [21].

\section{Research Methods}

\subsection{Data Collection Technique}

\subsubsection{In-depth Interview}

An interview is a question and answers conversation between three people, where one of them aims to explore and obtain information for a particular purpose. Interviews will be conducted in-depth and democratically to the batik owner. It is said to be an indepth interview because the aspects interviewed are related to aspects that can be recognized and involve aspects that are behind the emergence of a phenomenon. In-depth 
interviews were conducted many times and required time with informants at the research site to find out information about product development through the Halal Product concept. Interviews will be shown on the main informant, namely the owner (several Batik home industries) in the opposite city. The second informant is a supporter, namely consumers who are shopping (several Jambi batik shops).

\subsubsection{Observation}

Observation is a data collection method to obtain data in field research which is used to collect research data through observation and what is seen in the field (sensing). Researchers directly conduct reviews and observations of the research location, starting from the finishing process until the goods are marketed.

\subsubsection{Documentation}

Documentation is one of the techniques for obtaining data through data found in the field, transcript notes, photographs related to the subject, and the focus of this research.

\section{Result and Discussion}

\subsection{Type Of Coloring Used}

Based on the research that has been done, the Jambi Batik Industry is not sure that the Batik they manage can be categorized as an environmentally friendly product. This is because they use not only natural dyes but also use synthetic dyes and basic materials. Batik craftsmen prefer synthetic dyes due to the ease of obtaining synthetic dyes and uncomplicated use. In contrast to natural dyes, respondents said there was no difficulty in getting materials to process plant roots, leaves, and seeds into natural dyes. However, the processing process is quite complicated, and the process takes a long time.

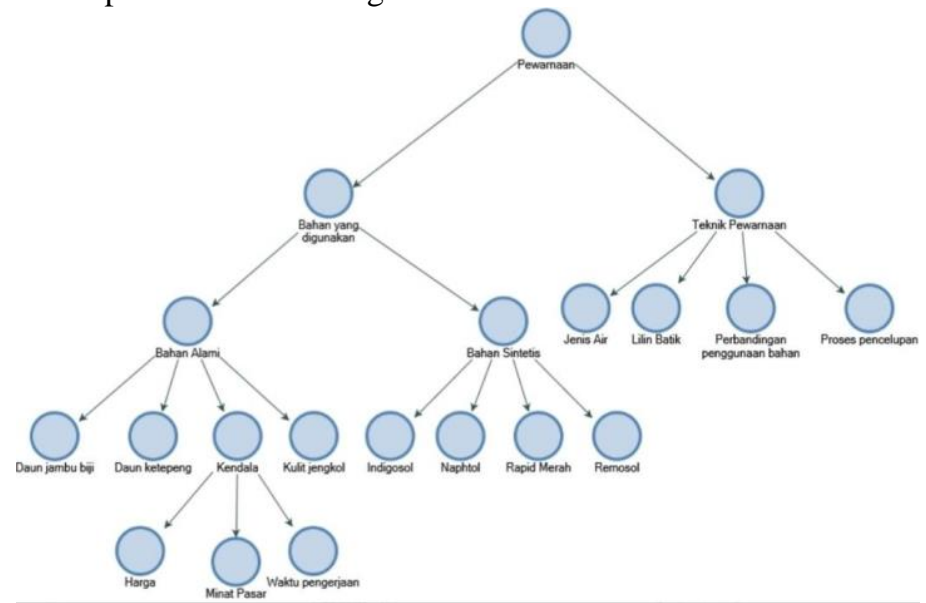

Fig. 1. Visualization of sub-themes regarding batik coloring. 
Long because you have to be careful, if you are not careful in the coloring process, then the color results can be striped or unclear. The types of synthetic materials used are Naphthol, Indigosol, Rapid Merah, and Remosol. At the same time, the natural ingredients used include jengkol skin, guava leaves, and ketepeng leaves. Synthetic materials produce bright colors, while natural materials are used to create soft colors.

The batik house has two methods of Batik, namely stamped and written Batik, which the craftsmen do in their respective homes, then the coloring is done at the batik house.

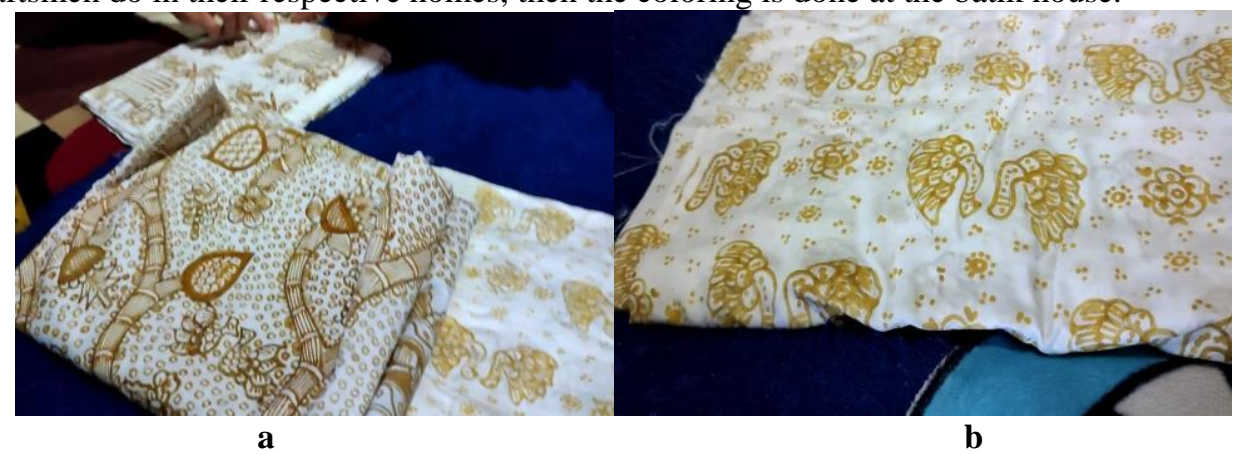

Fig. 2. Batik before coloring a. Written Batik b. Stamped Batik.

The dyeing of Jambi batik is done repeatedly; one color is dyed three times. For example, red is dyed three times back and forth. Naphthol color is dyed three times in the front and three times behind so that the total is dyed six times, in contrast to indigo sol color, which is dyed and dried three times. The dyes used in batik dyeing are naphthol and salt, reactive dyes (remosol), soluble vessel substances (indigo sol), rapid red, and natural dyes. Natural dyes used include jengkol skin, guava leaves, and ketepeng leaves. And z at color Naphthol consisting of components and component naphthol as the base color of the salts naphthol. Indigosol dyes, often also called soluble vessels, are dyed with good fastness and have a bright color. The color will appear after being raised with acid, either sodium nitrite or sulfuric acid, or hydrofluoric acid. Rapid dye is a mixture of naphthol components and stabilized diazonium salts, and the most commonly used is rapid red. Reactive dyes or remasol are dyes that are soluble and easily react with cellulose fibers

For three times naphthol immersion, then three times naphthol, and then salt. All kinds of colors are good, but sometimes the colors in naphthol are not in indigo sol, and vice versa, the colors in indigo sol are not in naphthol. According to the understanding that naphthol batik produces waste while indigo sol does not produce waste, Indigosol is directly dried in the sun and evaporates, while naphthol contains liquid waste. The indigo sol liquid is completely absorbed by the fabric and leaves only a tiny amount of waste. Both are synthetic dyes that are harmful and pollute the environment.

In contrast to natural dyes. The natural ingredients commonly used are jengkol skin, guava leaves for light brown color, ketepeng leaves for yellow, and noni root. For natural materials usually produce soft colors.

In the dyeing process to produce red liver or maroon, the color only consists of naphthol, but there is also naphthol and salt. The dose of naphthol is 1:3, one for naphthol and 3 for salt; for example, red liver naphthol is ASDO, and the salt is pink-red. This also applies to indigo sol, naphthol indigo sol uses hot water, and salt uses cold water. The cold water used is plain cold water, not ice water. The batik dyeing process uses two containers, the first is for naphthol and the second is for salt, then wet the cloth using a TRO which functions for 
absorption then dip the cloth into naphthol then dip it in salt, wash and wait for it to dry then repeat for three times. Jambi batik makers also prefer to use synthetic dyes because they are more in demand by the community. There is a difference in color interest if they are more interested in striking colors in rural areas than people living outside the city and outside the province. In contrast to foreign tourists who stop by in Jambi, they prefer natural dyes because those produced from natural dyes are softer, and they also have a high sense of environmental care.



a

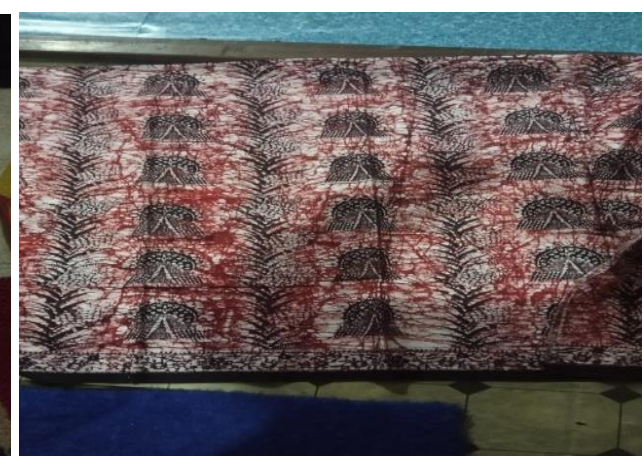

b

Fig. 3. a. Batik using synthetic dyes b. dyes using natural dye.

Colored liquid waste has a harmful content because there are chemicals in activities that are harmful to living things. The content of colored liquid waste also contains heavy metals such as chromium $(\mathrm{Cr})$, lead $(\mathrm{Pb})$, Nickel $(\mathrm{Ni})$, copper $(\mathrm{Cu})$ and manganese $(\mathrm{Mn})$ (Deliza et al.), and others, these metals are sourced from dyes containing $\mathrm{CrCl}_{3}, \mathrm{~K}_{2} \mathrm{Cr}_{2} \mathrm{O}_{7}$ and other sources derived from color binders such as $\mathrm{Cr}\left(\mathrm{NO}_{2}\right)^{2}$, besides that batik waste also contains carbohydrates, proteins and fats or oil. Heavy metals, when entering the food chain, are toxic which can cause death in organisms. Organic pollutants also play a substantial role in causing aesthetic damage, which contains pathogenic bacteria such as Salmonella spp., Escherichia coli, and others, causing various diseases such as diarrhea.

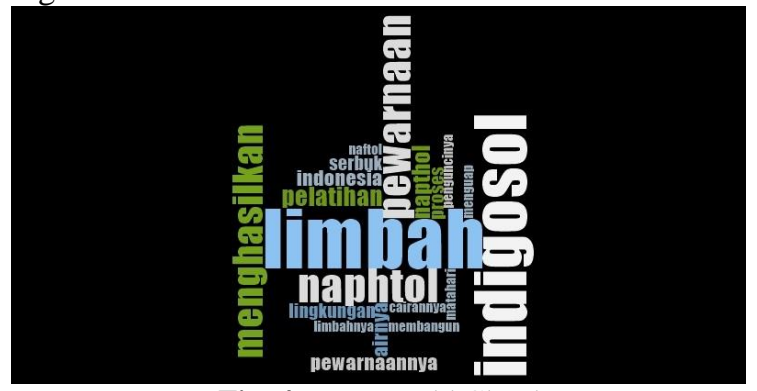

Fig. 4. New World Cloud

The use of synthetic dye produces non-biodegradable organic compounds and can spend oxygen cause taste and unpleasant smell on the availability of clean water surrounding. Synthetic dyes are divided into autochrome groups consisting of $-\mathrm{NH}_{2},-\mathrm{OH},-\mathrm{SH}$ groups. Meanwhile, the chromophore group plays a role in color appearance [22]. One of the chromophore groups is azo $(\mathrm{N}=\mathrm{N})$, dye remediation can be carried out anaerobically with the help of azoreductase enzyme. Azo dyes cannot be used as a source of nutrition because they are stable. 
Then the use of candles causes odors due to the activity of anaerobic bacteria. The use of phenol as a dye solvent is included in the aromatic hydrocarbons, which are toxic, flammable and corrosive, and harmful to the environment and organisms.

Although batik makers know that synthetic dyes produce far greater waste than natural dyes, batik makers are more likely to use artificial dyes in the batik coloring process. Constraints encountered by batik makers in using raw materials include relatively long processing times, uncompetitive prices, and market interest. This is revealed from the following batik maker's statement:

"Naphthol produces liquid waste that can damage the environment, while indigo sol is directly dried in the sun and then evaporates. The natural material still makes waste, but it is more environmentally friendly because it comes from nature. "

"The raw materials are easy to get, but it takes a long time to wait, and it takes a long time to do it; you have to be careful because if there is a wrong coloring, the color will become striped."

"The price of Batik is determined by way of Batik or the process of making Batik, the subtlety of Batik, the basic ingredients of batik cloth, and in terms of natural and chemical coloring that does not fade easily. Batik with natural colors has sold for a long time. Finally, we sell it at the same price as Batik that uses synthetic dyes".

Batik craftsmen have been learning batik coloring itself from generation to generation because this is a family business. Still, there is an opportunity for craftsmen to participate in a training held by the government in dyeing Batik, which appears in various colors, including soft colors such as nude and others.

\subsection{Type Of Coloring Used}

One of the aims of this research is to explore the process of batik waste management carried out by Jambi batik craftsmen. When the researcher asked about the knowledge of the batik makers on the waste produced from the batik coloring process, it was seen that the batik makers already knew about it. However, the knowledge of Batik about the waste generated from the batik coloring process is not entirely correct. This is revealed from the following statement:

"Naphthol produces waste, indigo sol does not produce waste. Indigosol is directly dried in the sun and evaporates, while naphthol has liquid waste".

Then all this time, Batik has been managing batik dye waste using a separation technique using a waste container filled with sand, gravel, and fibers. This can be seen from the following batik statement:

"There is a waste tub 1, tub 2. There are 3 meters like a well."

"We built two wells with a depth of 3 meters; later, the wells will be made of pipes/connectors. So, for example, this one is full. The other uses a hose/pipe to move to the other side. But later on, gravel, sand, palm fiber are given for deposition. Already settled and clear, the water moves to another tub. And the powder settles to the bottom."

According to the batik makers, the batik waste contained in the third reservoir contains relatively no harmful substances anymore. It can be seen from the following expression:

"In tub three, the water is clear, so it is easy to absorb into the ground. But it is possible to pollute the environment still". The results of the word search visualization for the word waste from the NVivo 12 Plus are as follows: 




Fig. 5. visualization for the word waste from the NVivo 12 Plus

From the visualization above, it can be seen that the knowledge of batik makers on the liquid waste resulting from the Jambi Batik coloring process is still minimal. It cannot be done only by a simple process using well-containing sand, palm fiber, and gravel in managing batik wastewater. Batik wastewater contains a lot of synthetic dyes containing heavy metal elements. In addition, the batik process also uses paraffin wax in the form of solid hydrocarbon compounds produced from petroleum. Wastewater managed by a biofilter using gravel, sand, and palm fiber can only overcome wax waste from Batik. However, it is not entirely safe if it is discharged into the environment because the paraffin wax waste will also settle and survive in the vicinity, such as on the sand bottom of the Batanghari River. Likewise, with their perception of dye waste, there is no continuing research on the wastewater contents in tub 1 , tub 2, and tub 3.

Dyestuff waste is a complete dye waste containing carbohydrates, fats, and even heavy metals such as chromium $(\mathrm{Cr})$, lead $(\mathrm{Pb})$, Nickel $(\mathrm{Ni})$, copper $(\mathrm{Cu})$, and manganese $(\mathrm{Mn})$ (Deliza et al.) lost by inserting it into three wells that are given sand and fibers, because heavy metals require a good and correct filtering process so as not to give biological disturbances or adverse effects on the surrounding environment.

Meanwhile, Naphthol, Indigosol, Remosol, and Rapid red are synthetic chemical dyes that are non-biodegradable and difficult to decompose in the environment. Synthetic chemical compounds also have strong polluting power with high Chemical Oxygen Demand (COD) and Biological Oxygen Demand (BOD) values. They can cause pollution on the water's surface that humans will use, damage aquatic life and ecosystems, cause unpleasant odors. Delicious, produces mud which causes blockages and can cause flooding.

\subsection{Batik Color Processing And Batik Perception}

In the final stage of the Jambi Batik dyeing process, batik craftsmen usually throw water from batik soaking into the Batanghari River. The Jambi Batik Industry, which is located along the banks of the Batanghari River, makes it easier for them to dispose of their waste without processing it first. This can be directly felt the impact of batik wastewater. Wastewater from the Jambi Batik processing has the impact of polluting the Batanghari River. In addition, the direct impact on Jambi Batik craftsmen is their skin irritation due to direct contact with waxes containing paraffin, detergents, and dyes containing naphthol and lead. Pollution occurs because of Jambi Batik craftsmen's lack of knowledge and awareness to choose products, dyes, and coloring processes and manage them effectively and 
environmentally friendly. The batik craftsmen also do not know the pollutants from the chemicals they use.

Batik craftsmen actually tend to have a concern for the state of the environment. They get information about the dangers and the importance of the environment through the internet. Not only from the internet, but batik makers also often get advice from parents, in the past, from educated brothers and sisters and the surrounding community to keep the environment clean and handle the industrial waste. For batik makers, using environmentally friendly materials and processes for making Batik is essential for survival. Still, some batik makers have not thought about changing the materials to make Batik more ecologically friendly. This is because they have not found materials that can benefit, such as non-environmentally friendly chemicals that batik makers use, such as darker colors, lower prices, etc.

In the selection of batik dyes, producers usually get information through the internet. On the internet, producers look for materials that are recommended to be environmentally friendly. An environment is where living things live where we are assigned to keep them from being damaged. As someone who works and manages the industry, innovating and creating an environmentally friendly product is essential, especially in Jambi province. Jambi is one of the provinces that produce Batik. Of course, a lot of waste is generated by industrial production. Therefore, a producer needs to make innovations in creating environmentally-friendly Batik by using materials that do not contain non-biodegradable properties. (hard to break down).

The batik makers will start using materials and making Batik that is more environmentally friendly if one or more batik industries using ecologically friendly materials get a large enough profit and experience a significant increase. The batik makers will begin to consider this, considering that the materials currently used are difficult to decompose and can damage the environment. Minimizing materials that are difficult to decompose is important for every industry, one of which is the Jambi Batik industry. This is because these materials can damage the environmental ecosystem around the industry, ranging from water, animals, humans, and so on.

According to the batik makers, the dyes used as dyes for batik cloth are not so dangerous. They only have a small impact on the environment, which is considered normal. They explained that the dye provides many benefits for the home batik industry. At the last stage of coloring, the dye can no longer be used. Generally, dyes can only be used once to produce a beautiful color. The dye can then be disposed of directly into landfills, soil, or directly into the environment.

The waste treatment carried out by batik makers based on interviews with the batik house owners explained that they drained it into three wells connected by pipes from wells one to two and two to wells three. The wells that Jambi batik manages are given cement, sand, palm fiber, gravel, and then they are cast. This means that when the first well is full, it flows to the next well closed, but in the third well, they do not add sand, palm fiber, and gravel because Jambi batik makers are sure that the batik wastewater in the third well is clean. Even in the third well, the water will stop, so there will be a possibility that it will be full and widen into the environment and water bodies. So far, there has been no specific test on dye waste in hole one and so on. To manage batik wastewater is not that simple. Water batik waste contains many synthetic dye-containing heavy metal elements. In addition, the batik process also uses paraffin wax in the form of solid hydrocarbon compounds produced from petroleum. In the management of batik wastewater, a good filtering process is needed because if we only use sand, fibers, gravel, the wastewater does turn clear, but synthetic ingredients such as paraffin wax are used to draw Batik, dyes, sodium sulfate, sodium carbonate and sodium bicarbonate 
in the water remains. This can cause biological disturbances in the water due to chemical oxygen depletion (COD), and the water still has a high $\mathrm{pH}$.

The owner of the batik house also explained that in the last two years, there had been attention from the government by developing an installation with filter technology using five filters, but in the middle of the construction work, there are problems so that until now it cannot be used. Not all Jambi Batik owners are given facilities for the management of dyestuffs. Only seven batik owners are in the location of Kampung Limo. Installation with filter technology is essential because it can change the $\mathrm{PH}$ of the water to be neutral and safe when flowing into the Batanghari River. During the filtering process, the filter can remove dyes and waxes and minimize the $\mathrm{PH}$ of the water, which causes the return of the effectiveness of oxygen in the water when the filter results are drained into the Batanghari River.

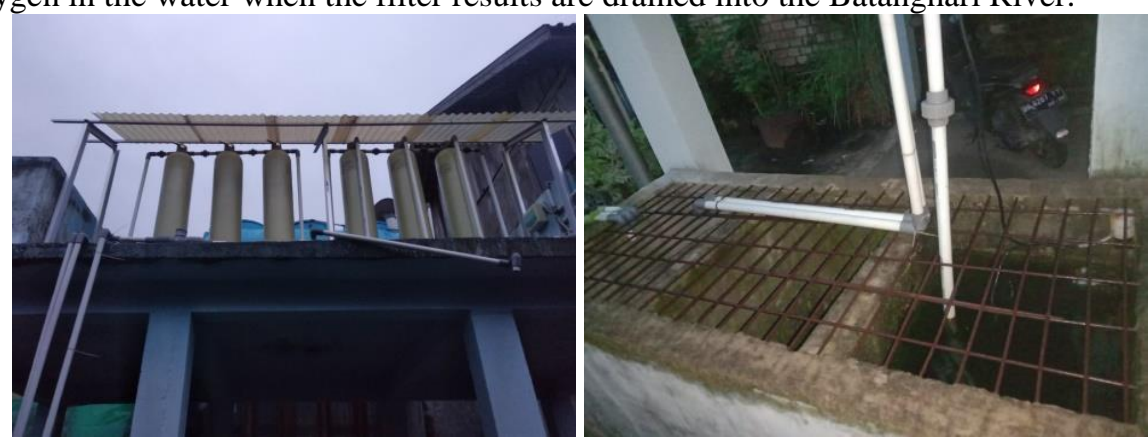

Fig. 6. Installing a filter tool from the government

Attention from the government and knowledge of Batik to manage batik wastewater is still minimal. It is pretty natural that the batik industry in Jambi is still unable to create an environmentally friendly batik industry. However, this is also possible because of the curiosity of Jambi batik makers to manage wastewater. With training, they have been able to apply the biofilter process to water using natural materials such as sand, gravel, and palm fibers. It is also essential for scholars and academics to inform about the management of batik wastewater. Batik wastewater can be minimized by choosing environmentally friendly materials, natural dyes, and effective use of supporting materials such as paraffin wax. The use of paraffin wax can be recycled to reduce one of the contents in batik wastewater. In addition, wastewater can be managed using coconut charcoal. In the research of [23]. Qisti et al., economical coconut charcoal can help the waste treatment process. Coconut charcoal has many and large pores that can help the absorption process. Further research is needed to manage wastewater effectively and environmentally friendly for batik SMEs in Jambi to create a sustainable industry

\subsection{Intervention From The Government}

The role of the Jambi City government can provide firm policies by making local regulations to manage wastewater to minimize environmental pollution. Scholar also has a role in providing insight into the dangers of synthetic dyes from Jambi Batik. The risks of synthetic dyes can be felt again in the future and cause cancer and mutagenicity in the Jambi community. Jambi Batik craftsmen do not manage waste in an environmentally friendly manner. This causes the Batanghari River water to be cloudy, smelly and has a brown color. It can be seen that Batanghari River water is not following the Indonesian National Standard on water quality for hygiene and sanitation purposes. The thing that needs to be done by Batik is 
to manage wastewater first or use wetlands with the help of sand to manage batik dye wastewater economically and effectively to create a sustainable and environmentally friendly industry.

\section{Conclusion}

The Jambi batik industry uses synthetic dyes such as naphthol, indigo sol, remosol, and rapid red. Jambi batik makers tend to choose synthetic dyes because they are easy to obtain and manage. Jambi batik's concern is already there, with them building a simple well using a biofilter of sand, palm fiber, and gravel. However, it does not entirely remove the synthetic dye content in the water. It is necessary to have advanced technology with relatively better filters to remove artificial dyes from Batik, such as lead, metal, chromium, sodium sulfate, and sodium bicarbonate.

Acknowledgments. Financial support for this research by Universitas Islam Negeri Sulthan Thaha Saifuddin Jambi gratefully acknowledged.

\section{References}

[1] A. P. Siregar et al., "Upaya Pengembangan Industri Batik di Indonesia," Din. Kerajinan dan Batik Maj. Ilm., vol. 37, no. 1, 2020, doi: 10.22322/dkb.v37i1.5945.

[2] Alamsyah, "Kerajinan Batik dan Pewarnaan Alami," J. Ilm. Kaji. Antropol., vol. 1, no. 2, 2018.

[3] K. Kristiningsih, L. Lestari, and W. Herawati, "Analisis Strategi Positioning Produk Berdasarkan Persepsi Konsumen Pada Industri Batik Di Jawa Timur," MANAJERIAL, vol. 8, no. 01, p. 85, Jan. 2021, doi: 10.30587/manajerial.v8i01.1975.

[4] H. I. Elmiani, "Motivasi Milenial Pada Penggunaan Outfit Batik," pp. 2-3, 2020.

[5] N. P. Setianingrum, A. Prasetya, and S. Sarto, "Pengurangan Zat Warna Remazol Red Rb Menggunakan Metode Elektrokoagulasi Secara Batch," J. Rekayasa Proses, vol. 11, no. 2, 2018, doi: 10.22146/jrekpros.26900.

[6] N. K. T. Martuti, I. Hidayah, M. Margunani, and R. B. Alafima, "Organic material for clean production in the batik industry: A case study of natural batik Semarang, Indonesia," Recycling, vol. 5, no. 4, 2020, doi: 10.3390/recycling5040028.

[7] Hamsuri, Batik Klasik=Classical Batik. Djambatan, Jakarta, 1985.

[8] S. Doelah, Batik:Pengaruh Zaman dan Lingkungan. Danar Hadi, Solo, 2002.

[9] I. Eny Kustiyah, "Batik Sebagai Identitas Kultural Bangsa Indonesia Di Era Globalisasi," Gema, vol. 30, no. 52, pp. 2456-2472, 2017.

[10] Syakur, Indonesia Indah : Batik. Yayasan Harapan Kita, Jakarta, 1997.

[11] I. N. Sukarta, "Sintesis Membran Nata De Pina Dan Aplikasinya Untuk Adsorpsi Zat Warna Tekstil Remazol Red Rb,” J. Kim., vol. 14, no. 2, p. 134, 2020, doi: 10.24843/jchem.2020.v14.i02.p05.

[12] B. Gratings, "Print90 3_4_2_2 - instrumentation - echantillon.mp4 00:00:00," pp. 4-5, 2019.

[13] Enrico, "Dampak Limbah Cair Industri Tekstil Terhadap Lingkungan dan Aplikasi Tehnik Eco Printing sebagai Usaha Mengurangi Limbah," Moda, vol. 1, no. 1, pp. 5-13, 2019.

[14] N. T. T. Hoang, A. T. K. Tran, M. H. Hoang, T. T. H. Nguyen, and X. T. Bui, "Synergistic effect of TiO2 /chitosan/glycerol photocatalyst on color and COD removal from a dyeing and textile secondary effluent," Environ. Technol. Innov., vol. 21, p. 101255, 2021, doi: 10.1016/j.eti.2020.101255.

[15] P. Cesar da Silva, G. Cardoso de Oliveira Neto, J. M. Ferreira Correia, and H. N. Pujol Tucci, "Evaluation of economic, environmental and operational performance of the adoption of cleaner 
production: Survey in large textile industries," J. Clean. Prod., vol. 278, 2021, doi: 10.1016/j.jclepro.2020.123855.

[16] J. Liu et al., "Microfiber pollution: an ongoing major environmental issue related to the sustainable development of textile and clothing industry," Environment, Development and Sustainability, vol. 23, no. 8. 2021, doi: 10.1007/s10668-020-01173-3.

[17] A. M. Fauzi and R. L. Defianisa, "Analysis for cleaner production implementation strategy in batik industry in Bogor," in IOP Conference Series: Earth and Environmental Science, 2019, vol. 325, no. 1, doi: 10.1088/1755-1315/325/1/012005.

[18] C. Frimpong, "A Combined Material Substitution and Process Change Approach to Sustainable Batik Production," Latest Trends Text. Fash. Des., vol. 1, no. 1, 2018, doi: 10.32474/lttfd.2018.01.000104.

[19] Y. A. Romadhon, "Kebijakan Pengelolaan Air Limbah Dalam Penanganan Limbah Batik Di Kota Pekalongan," Insign. J. Int. Relations, vol. 4, no. 02, 2017, doi: 10.20884/1.ins.2017.4.02.667.

[20] W. Handayani, A. I. Kristijanto, and A. I. R. Hunga, "Are natural dyes eco-friendly? A case study on water usage and wastewater characteristics of batik production by natural dyes application," Sustain. Water Resour. Manag., vol. 4, no. 4, 2018, doi: 10.1007/s40899-018-0217-9.

[21] K. Raharjo, "The role of green management in creating sustainability performance on the small and medium enterprises," Manag. Environ. Qual. An Int. J., vol. 30, no. 3, 2019, doi: 10.1108/MEQ03-2018-0053.

[22] D. Deliza, A. Syukri, M. N. Wulanda, and D. Sartika, "Detection of metal elements within Inductively Couple Plasma Emission Jambi batik waste and views as Muslim education," J. Phys. Conf. Ser. , IOP Publ., vol. 1869, no. 1, p. 012059, 2021, doi: 10.1088/1742-6596/1869/1/012059.

[23] A. Qisti, Y. Utomo, and D. A. Rokhim, "Treatment of Dye Wastewater from Batik Industry by Coconut Shell Activated Carbon Adsorption," Fuller. J. Chem., vol. 6, no. 1, 2021, doi: 10.37033/fjc.v6i1.213. 